Portland State University

PDXScholar

\title{
A study of the incidence of divorce, religious conflict, and need and potential utilization of marital/family services among Seventh-Day Adventist couples in the North Pacific Union Conference
}

Fern M. Ringering

Portland State University

Follow this and additional works at: https://pdxscholar.library.pdx.edu/open_access_etds

Part of the Christian Denominations and Sects Commons, Family, Life Course, and Society Commons, and the Social Work Commons

Let us know how access to this document benefits you.

\section{Recommended Citation}

Ringering, Fern M., "A study of the incidence of divorce, religious conflict, and need and potential utilization of marital/family services among Seventh-Day Adventist couples in the North Pacific Union Conference" (1978). Dissertations and Theses. Paper 2757.

https://doi.org/10.15760/etd. 2743

This Thesis is brought to you for free and open access. It has been accepted for inclusion in Dissertations and Theses by an authorized administrator of PDXScholar. Please contact us if we can make this document more accessible: pdxscholar@pdx.edu. 
A STUDY OF THE INCIDENCE OF DIVORCE, RELIGIOUS CONFLICT, AND NEED AND POTENTIAL UTILIZATION OF MARITAL/FAMILY SERVICES AMONG SEVENTH-DAY ADVENTIST COUPLES

IN THE NORTH PACIFIC UNION CONFERENCE

\title{
by
}

FERN M. RINGERING

\begin{abstract}
A Research Project Presented to the FACULTY OF THE SCHOOL OF SOCIAL WORK PORTLAND STATE UNIVERSITY
\end{abstract}
In Partial Fulfillment of the Requirements for the Degree
of

MASTER OF SOCIAL WORK 
TO THE OFFICE OF GRADUATE STUDIES AND RESEARCH:

This research project of Fern Marie Ringering is presented March 1, 1978 for approval.

APPROVED:

Nancy Qoroloff, MSW, Assistant Professor

Portland State University School of Social Work 


\section{ACKNOWLEDGEMENTS}

This report is the product of the researcher's interest in the helping professional's role in the quality of Seventh-day Adventist family Iife. The area of study concentration grew out of a desire to understand some of the dynamics of the Seventh-day Adventist lifestyle in our changing contemporary society and the needs for enhancing that way of life, as seen by the church members themselves.

I am grateful to the church officials of the North Pacific Union Conference of Seventh-day Adventists who gave support and encouragement to the research project.

I also wish to express my appreciation to the church members of the North Pacific Union Conference of Seventh-day Adventists who participated in the study and contributed so richly to the data collection process.

Finally, I want to thank Nancy Koroloff, MSW, my faculty research advisor for her guidance and encouragement throughout the project's development.

F. M. R. 
TABLE OF CONTENTS

PAGE

ACKNOWLEDGEMENTS . . . . . . . . . . . . . . . . . . ii

IIST OF TABLES . . . . . . . . . . . . . . . . . . . v v

ILLUSTRATIONS . . . . . . . . . . . . . . . . . . vii

CHAPTER

I INTRODUCTION •. . . . . . . . . . . . . . . 1

Seventh-day Adventists: A Brief Overview . . . . 6

Organization . . . . . . . . . . . . 6

Membership . . . . . . . . . . . . 8

Lifestyle and History . . . . . . . . . . 8

Adventists and Charity . . . . . . . . . 10

II RESEARCH DESIGN • . . . . . . . . . . . . . 15

Introduction . . . . . . . . . . . . 15

Sampling . . . . . . . . . . . . . . . 17

Questionnaire .. . . . . . . . . . 18

Questionnaire Description .. . . . . . . 19

Pilot Study . . . . . . . . . . . . . 22

III RESEARCH FINDINGS . . . . . . . . . . . . . . 24

Introduction .............. . 24

Response to Questionnaire ........... 25 
PAGE

Return Rate ... . . . . . . . . . 25

Return by Geographical Areas . . . . . . . . 26

Return by Sex . . . . . . . . . . . . 27

Nonrespondents . . . . . . . . . . . . 27

Description of Respondents . . . . . . . . . 29

Issue 1. Is Religious Belief Or Practice A Major

Source of Conflict In SDA Marriage . . . . 32

Issue 2. What Is The Ineidence of Divorce Among SDA Members ............... 33

Issue 3. Do Seventh-day Adventists See Themselves As Needing Marital/Family Services? Would They Utilize Such Services If Available From SDA Professionals ......... 36

Related Questions . . . . . . . . . . 41

IV CONCLUSIONS AND RECOMMENDATIONS . . . . . . . . . 45

Introduction .............. . 45

Response of Sample Members . . . . . . . . 48

Divorce Among Seventh-day Adventists . . . . . . 49

Religious Conflict In Marriage . . . . . . . 54

Need For Seventh-day Adventist Family And Marital Services........... 58

Possible Utilization of SDA Professional Services . 59

APPENDICES

A. Cover Letter for Questionnaire . . . . . . . 63

B. Family Life Survey . . . . . . . . . . . 64

C. Cover Letter for Pilot Questionnaire . . . . . . 69

D. GLEANER News Item . . . . . . . . . . . . . 70

E. Summary Sheet Given to Conference Officials . . . . 71

SELECTED BIBLIOGRAPHY . . . . . . . . . . . . . . . 73 


\section{LIST OF TABLES}

TABLE

PAGE

I Questionnaires Mailed to Selected Sample . . . . . .

II North Pacific Union Conference Membership

Distribution Compared to Questionnaires

Returned Per Conference . . . . . . . . . 27

III Reasons For Nonresponse . . . . . . . . . . . . 29

IV Ages of Respondents by Categories . . . . . . • . . . 29

V Income Levels of Questionnaire Respondents . . . . . . 30

VI Church Attendance Patterns of Respondents . . . . . . . 31

VII Respondents Reporting Religious Conflict in

Their Marriage . . . . . . . . . . . . 33

VIII Respondents' Membership Status at Time of Divorce . . . 35

IX Spouse Membership Status for Members Divorced

While SDA Member . . . . . . . . . . 35

X Divorced Respondents' Attitudes Toward Counseling . . • 36

XI Problem Areas in Marriage Relationship as Reported

by Respondents (By Rank) . . . . . . . . . 37

XII Respondents' Suggestions on How Their Church Could

Help Enrich or Strengthen Their Family Life . . . 38

XIII Source of Marital Counseling Received

By Respondents . . . . . . . . . . . . 39

XIV Type of Counselors Preferred by Respondents . . . . . . 40 
XV Respondents' Reasons for Nonutilization of Counseling Services . . . . . . . . . . . 40

XVI Respondents' Attitudes Toward Family Enrichment

Programs . . . . . . . . . . . . . . 41

XVII Top Five Major Factors in Marriage Breakup as

Listed by Divorced Respondents (By Rank) . . . . . 42

XVIII Satisfaction in Family Iife Compared to Church

Attendance Patterns . . . . . . . . . . . 43

XIX Church Attendance Compared to Religious Conflict

In the Home . . . . . . . . . . . . 43

XX Reported Strengths in Marriage (By Rank) . . . . . . . 44 
ILLUSTRATIONS

PAGE

1. Flow Chart of Church Organization ......... . 7

2. Degree of Happiness . . . . . . . . . . . 31 
CHAPTER I

INTRODUCTION

Social Work is defined in many different ways, depending upon the personal viewpoint and values of the person writing the definition. Ruth Smalley says,

The underlying purpose of all social work effort is to release human power in individuals for personal fulfillment and social good, and to release social power for creation of the kinds of society, social institutions, and social policy which makes self-realization most possible for all men. 1

The National Association of Social Workers defines its practice in this way, "Social Work Practice like the practice of all professions, is recognized as a constellation of value, purpose, sanction, knowledge and method." ${ }^{2}$ Skidmore and Thackeray assert that,

Social work may be defined as an art, a science, a profession which helps people solve personal, group and community problems, and to attain satisfying personal, group and community relationships through use of certain methods including casework, group work, community organization, and the enabling processes of research and administration. Social work not only helps people solve problems, but also assists them to prevent problems and enrich daily living. 3

${ }^{I}$ Ruth A. Smally, Theory For Social Work Practice (New York: Columbia University Press, 1967), p. l.

2 Elizabeth Fergusen, Social Work: An Introduction (Philadelphia: Lippencott, 1969), p. 7 .

${ }^{3}$ Rex Skidmore and Milton Thackery, Introduction to Social Work (New York: Appleton-Century-Crafts, 1964), p. 8. 
Others see social work as a method of regulating society, quieting unrest, a balance in our capitalistic society. Piven and Cloward, in their book, Regulating the Poor say,

We argue that expansive relief policies are designed to mute civil disorder, and restrictive ones, to reinforce work norms. In other words, relief policies are cyclicalliberal or restrictive depending on the problems of regulation in the larger society with which the government must contend. ${ }^{4}$

Social agencies sponsored by religious groups, however, feel that other elements must also be included for social work to be truly effective. One such primary element is charity. It is to this element that many of these sectarian agencies point as the justification for their very existence.

Perhaps the most venerable component of the philosophy behind social work practice is charity. As practiced by Christ, charity is synonymous with love. However, it is not by Christ's example alone that Christians are moved toward charitable acts, for the Scriptures exhort them to care for the widows and orphans and the poor. Christ Himself said, "Inasmuch as ye have done it unto the least of these My brethren, ye have cione it unto Me." Matthew 22:40. Even the most repulsive, forlorn and downtrodden, from this point of view are deserving benevolence. From Christ's time on, and well into more modern times, the church has been the primary means of serving the poor and other outcasts of society.

4 Frances Fox Piven-Richard A. Cloward, Regulating the Poor (New York: Random House, 1971) Introduction. 
The Judeo-Christian belief as expressed in the old and the New Testaments, which conmanded that the needy be served, was perhaps the earliest formalization beyond the family of a concern for the poor, the sick and the aged. 5

In medieval England, the poor were accepted as unfortunates whom the fortunates were normally obligated to help. The help was provided through churches, monasteries, guilds, and other benevolent groups. In the Tudor period, the parish, (the local governmental unit analogous to contemporary counties) organized the provision by parceling out responsibility for the poor to both religious and secular organizations. Gradually a series of societal changes created an increasing strain in the existing systems and eventually led to modifications which began our era of the present day welfare system. 6 Even with the development of secular social welfare, beginning in the early part of this century and mushrooming to our present social welfare system, religious groups continue to play an active part in supplying a wide variety of services to not only their constituents, but multitudes of others as well.

YMCA, YWCA, Lutheran Family Services, Jewish Family Services, Jewish Community Ctnters, Catholic Social Services, the Salvation Army, and many other sectarian groups contribute to the well-being of immigrants, low-income urban dwellers, the rural poor, and other "needy" categories. In addition, they supply many services to the more affluent. When orphanages were in their heyday a few decades ago, there

${ }^{5}$ Phillip Klien, From Philanthropy to Social Welfare (San Francisco: Josey-Bass, 1968), p. 10.

$6_{\text {See Paul A. Kurzman, Relief in Medieval England - The Forgotten }}$ Chapter in the History of Social Welfare, Child Welfare \#49 (November 1970): pp. 495-501. 
were nearly one thousand such institutions in the United States with sectarian sponsorship. ${ }^{7}$ In more recent years, with unemployment, welfare, food stamps, subsidized rent and other governmental programs geared to alleviating the plight of the poor, many religious groups have changed their focus. These agencies are now providing specialized services such as day care, emergency food and housing, or counseling services.

Some churches, such as the Latter-day Saints provide a wide variety of services, but such services are primarily for their own membership. Other churches provide services, but these are used for the most part by others, rather than their members. An example would be Lutheran Family Services, a family counseling service, who, according to assistant director, Don Borjesson, see approximately 2,000 people annually in Portland. However, only about $5 \%$ of these are Lutheran.

A contrasting agency is Jewish Family Services. They see about 500 individuals in Portland each year, and Alvin Ragmere, executive director, states that over $75 \%$ of those served are of Jewish religious faith. He feels that this percentage is fairly typical of Jewish Family Agencies nationwide.

While Catholic Family Services in Portland, established in 1934 , is dedicated to "preserving and strengthening family and married life, and to fostering harmonious relations between family members, without discrimination as to creed, color, race or financial circumstances,"

${ }^{7}$ Martins Wolins, Institution or Foster Family, A Century Debate (Child Welfare League), p. 6 . 
the majority of those they serve are Catholic. The Sisters of Providence do operate two hospitals in the city of Portland whose services come under the broad definition of social welfare. Only about $20 \%$ of the patients using these facilities are Catholic. ${ }^{8}$

Blanchet House, The Salvation Army, and a number of missions are operated under religious auspices. In addition, many church groups have charity organizations within their memberships which provide a wide variety of social services including counseling, to a large clientele, the majority of whom are unchurched. In addition, as previously mentioned, many churches provide specialized services, especially counseling to their own members. While it appears that these services are more often than not informal, such as the pastor counseling a couple in his congregation concerning their troubled mastiage, this counseling forms the bulk of marital coungeling most ehureh-going couplés receitve. 9

The following study is designed to look at one religious group and assess some of the social service needs as seen by the study participants.

Since social services cover such a broad spectrum, it was decided to limit the study to marital counseling needs and related issues as seen by individual church members.

${ }^{8}$ Conversation with William Rooney, Agency Director, Portland Catholic Family Services.

${ }^{9}$ Determination made by researcher in review of literature. 
SEVENTH-DAY ADVENTISTS:

A BRIEF OVERVIEW

The Seventh-day Adventist church is a conservative Christian body, worldwide in extent, evangelical in doctrine, and professing no creed but the Bible. It places strong emphasis on the Second Advent (second coming of Christ) which it believes is near, and observes the Sabbath of the Bible, the seventh day of the week. These two distinguishing points are incorporated into the name Seventh-day Adventist. Seventh-day Adventist church members are frequently referred to as Adventists, or SDA (abbreviation of Seventh-day Adventist). In this paper the three names will be used interchangeably.

Organization

The church is administered by democratic organization ranging from the local church through the conferences and the unions, to the worldwide divisions and finally to the General Conference. Each of the conferences, unions, divisions and the General Conference have similar executive positions. As an example, each division has a president (who is vice-president of the General Conference), its officers, and its executives who belong to the General Conference Executive Committee, serving somewhat as a subcommittee operating in its own section of the globe. The same organization plan is practiced in the Unions and Conferences on a more local level. The highest executive in the overall organization is the president of the General Conference. A flow chart is provided to show the organization from the individual church member through the various organizational structures to the General Conference. (See Figure 1.) 
General Conference of Seventh-day Adventists
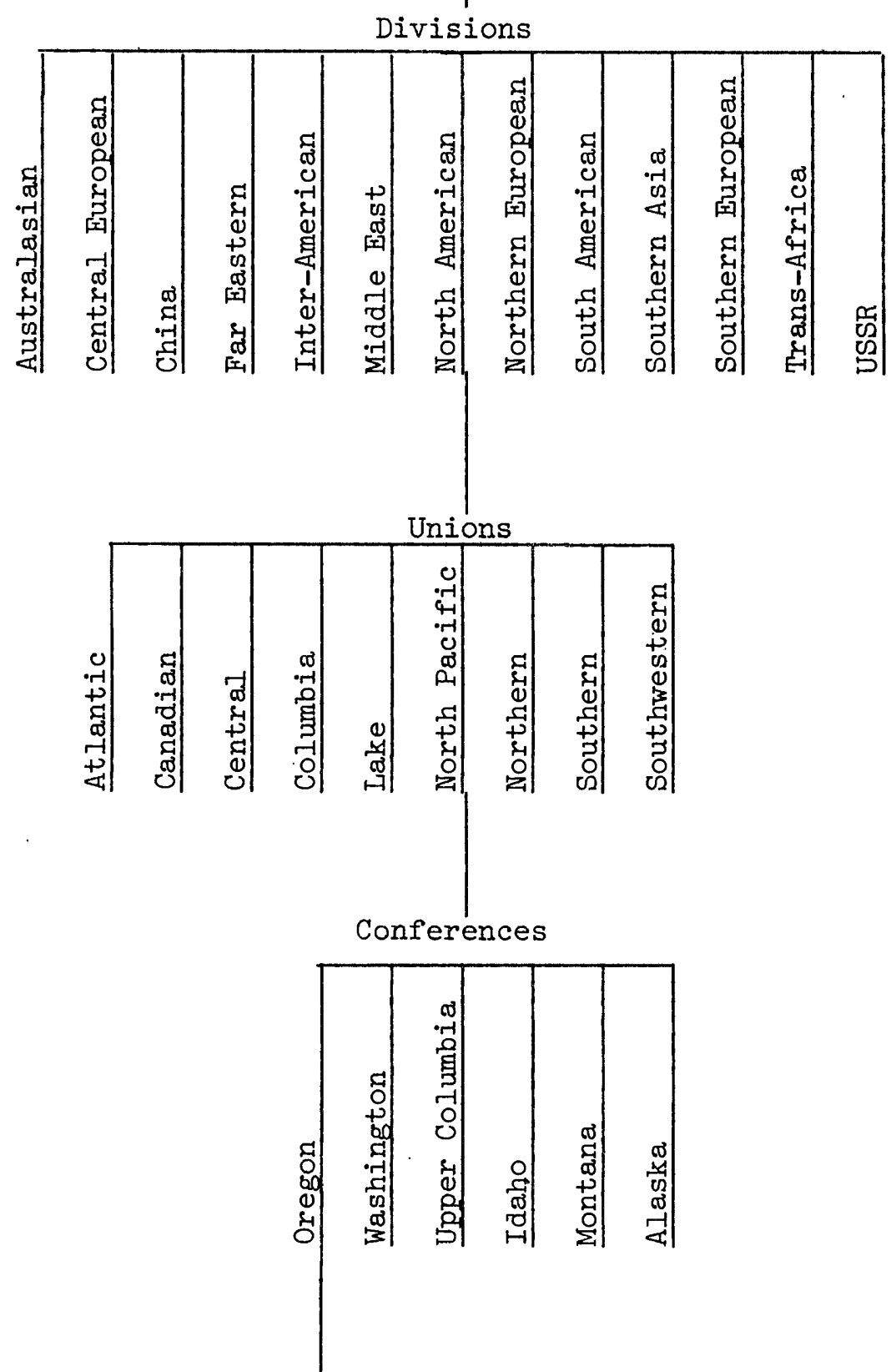

Churches

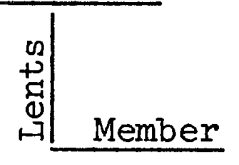

Figure 1. Flow chart of church organization. 
Membership

The 1976 worldwide membership of $2,727,022$ is distributed approximately as follows: one-fourth in North America, one-fifth in Latin America, one-fifth in Africa, one-sixth in Europe, one-seventh in Asia, and one-twentieth in Australia. Local conference membership in the USA varies greatly in numbers depending upon the geographical areas. Proportionately, there are many more Seventh-day Adventists on the West Coast than the East when compared with the general population figures. There are a number of large eastern cities with only one SDA church, while the greater Portland area as an example has approximately 20 churches. In the Oregon Conference, which includes all of the western area of Oregon, there are 107 churches with a total membership of $22,964.10$

\section{Lifestyle and History}

The Seventh-day Adventist lifestyle includes regular attendance at weekly church services conducted on Saturday in churches which are architecturally styled similarly to other Protestant churches. Adventists are active participants in church activities and carry many church responsibilities. These might include music ministries, teaching children's or adults' Bible lesson classes, clerical duties, custodial duties, providing community. services, and a variety of other church-related activities. Seventh-day Adventists abstain from tobacco and liquor. They have a strong emphasis on family life, and they participate in the church-sponsored educational system that

\section{${ }^{10}$ Seventh-day Adventist Yearbook $(1977$ ), p. 68 .}


provides schooling from kindergarten (in some areas) to graduate school. They contribute hedvily to maintain this school system in an era when many private schools are closing their doors because of financial problems. Adventists appear to be strongly motivated to live "Christ centered lives," most active Adventists will testify their daily lives and their activities center on their religious beliefs. Not only are they active in participation, but they support their church financially as well. Adventists give to their church four times as much as other churchgoers on a per capita basis. Seventh-day Adventists are in the majority vegetarian, and the use of natural food is strongly emphasized. ${ }^{11}$

Historically, the church was not formally organized until 1860 . However, its people had, since 1844, been distinguishable by their particular beliefs from others of the early widespread interest in the "Advent" that swept both North American and European religious circles of that day.

The most prominent of the Seventh-day Adventist church founders is Ellen G. White, writer, lecturer and counselor to the church, who possessed what Seventh-day Adventists have accepted as a prophetic gift. She is the author of the book The Adventist Home, after which most Seventh-day Adventist church members endeavor to pattern their homes. In addition, she has authored 54 books and 4,600 articles published in many church papers. She was active not only in the

${ }^{11_{\text {See }}}$ Seventh-day Adventist Fncyclopedia (Washington, D.C., Review and Herald Publishing Co., 1966), p. 1179. 
formation of her church, but served as its advisor until her death in 1915.12

Adventists and Charity

Seventh-day Adventists have been active in humanitarian work since the formation of their church. They currently operate an organization known as SAWS, which is an abbreviation of the name, SDA Welfare Service, Inc. This is an international organization established in 1956 for the purpose of operating the church's overseas disaster and famine relief programs. SAWS maintains close cooperation with Church World Service, CARE and other relief agencies. It is a member agency of CARE. In a typical year they will distribute, in perhaps 50 countries, a half million pounds of clothing and bedding, surplus foods valued at several million dollars, and medical and miscellaneous equipment valued at one-quarter million. SAWS has warehouses in California and also on the East Coast.

Another area of charity emphasis has been the establishment of a network of hospitals and clinics throughout the world to attend to the physical needs of thousands of people without means for other medical services. Seventh-day Adventists also operate community services centers which offer services such as Stop Smoking Clinics, vegetarian cooking classes, weight control seminars, and many other healthrelated educational services. Oregon has 50 of these centers scattered throughout the western part of the state.

In addition, each of the 107 churches in the Oregon Conference

${ }^{12}$ See Booth Herndon, 7 th Day, The Story of Seventh-day Adventists (New York, McGraw-Hill, 1963). 
has a "Dorcas Society," a type of ladies' aid society, which does charity work on a more local level than the SAWS organization. However, the local Dorcas society does prepare clothing for use by SAWS. The early charity activities of the church Dorcas society members might well be compared to the "lady bountifuls" and the "friendly visitors" which were their social work contemporaries. Like the social work profession however, Seventh-day Adventist humanitarian work has changed its emphasis through the years. In 1913, a Home Missionary Department was formed which was the national governing body of all the local Dorcas Societies. To this day, its head is a powerful member of the church's executive committee.

Seventh-day Adventists, while being very active in humanitarian work, have never developed social services specifically for their own members like the Latter-day Saints. Many of the larger SDA hospitals have social work departments, but this service is limited to the hospital patient. There are no family service agencies, such as Jewish Family Services, for Adventists with troubled marriages or problems with family relationships. However, church officials are aware that family and other social problems do exist within the church membership.

Elder Harris, Oregon's top church official, has on many occasions publicly stated that "contemporary living is taking its toll on the Adventist homes across the nation."13 Pastors continue to report increasing requests for counseling among their parishioners.

$13_{\text {Elder Harris in public address at the Oregon Conference }}$ Campmeeting, July 1977. 
Christian physicians, who were once a source of marital counseling for church members, seem to be increasingly advising their patients to seek marital counseling outside the medical field. Doctors interviewed state they do not have the time to spend in long counseling sessions needed for marital problems. Physical problems appear to be in priority among many doctors.

While many pastors continue to solemnize the marriage ceremony with the words, "till death do thee part," they know full well that many of these unions will sooner or later dissolve in separation or divorce. Some pastors feel a contributing factor to this breakup is differences in religious belief and practice of the marriage partners. Some contemporary marriage experts tend to agree. Gail Putney Fullerton in Survival in Marriage state,

People who have definite religious convictions find it difficult to live in emotional comfort with a husband or wife of a different religious faith. For them, religious edogamy is probably a prerequisite for marital happiness. If they do violate religious edogamy, conflict may be buried early in marriage, but as soon as there are children the latent religious conflict is likely to become divisive. 14

It would seem feasible to assume that Seventh-day Adventist members, who attest to a very real preoccupation with their church, might well be experiencing conflict with marriage partners who do not have the same religious convictions. Little research, other than the Carscallen and Reichert studies which will be mentioned briefly, has been done to study Seventh-day Adventist families. Thus, figures are

${ }^{14}$ Gail Putney Fullerton, Survival In Marriage (New York, Holt, Rinehart and Winston, Inc., 1972), p. 294. 
not currently available that give information on ratios of member/ nonmember marriages to marriages where both partners are members, and how this might be related to marital conflict. Figures are also not available on incidence of divorce among Adventists although it is assumed that because of the strong church emphasis on family life and the negative attitude the church formally takes on the issue of divorce, the rate among church members would be less than the national average.

There are two other research projects currently being conducted to study Seventh-day Adventist families. One is the Carscallen Adventist Family Life Study, being conducted by Lois Carscallen, a Doctor of Psychology candidate from the University of Idaho. The purpose of her study is to identify the standards Seventh-day Adventists in the Upper Columbia Conference (Eastern Washington) feel to be important to successful family life, and to determine the extent to which they perceive they are achieving those standards.

The other study is being conducted by Dr. Conrad Reichert, Associate Professor of Education, Andrews University. Its focus is Seventh-day Adventist members' attitudes toward divorce. (Neither of these studies address the issues this researcher is studying in the herewithin described research.)

While a number of professionals within the Seventh-day Adventist church feel more church-sponsored services designed to fill the particular needs of Seventh-day Adventists should be available, there is no hard data to support that a need for social services even exists, or if it does exist that such services would be utilized by church members. 
The remainder of this paper will describe a research project designed to gather data that would give insight to three of the issues previously mentioned.

1. Is religious belief or practice a major source of conflict in Seventh-day Adventist marriages?

2. What is the incidence of divorce among Seventh-day Adventist couples?

3. Do Seventh-day Adventists need and would they utilize churchsponsored counseling services if available?

While this study is limited to the above-mentioned issues primarily, opportunity is given to participants to expand their responses through several open-ended questions included in the data-gathering instrument. In addition, several other questions are included, that are related to the issues being studied, but do not address them directly. The purpose of including these questions is to gather data that will help in better understanding variables related to the issues. Hopefully, this data will be helpful in planning programs addressed to the issues under study. 
CHAPTER II

RESEARCH DESIGN

Introduction

This research on Seventh-day Adventist family life to gather data on incidence of divorce among Adventists, to study the relationship of religious commitment and marital conflict, and to assess, at least partially, the need for family counseling services and attitudes toward utilization of such services, was initially planned for church members in the state of Oregon only.

Permission was needed from Seventh-day Adventist church leaders for use of membership lists. Also cooperation and support of these Ieaders was essential for the success of the study, thus a first step in planning the design was contact with Oregon Conference officials. The initial meeting was with the conference President, Executive Secretary (similar to a vice-president), and the head of the Lay Activities Department, the department responsible for churchsponsored community and home education activities. They were positive in their comments about the need for such information and their cooperation with the project. However, this was at the time Oregon Conference executives were wrestling with a crisis in the secondary education program of the Conference. They suggested that perhaps the Union (next step higher in the organization) would be an appropriate sponsor. 
About this time a nationwide conference of department heads of the Lay Activities Departments was held in Portland. The researcher received an invitation to attend this meeting. This afforded opportunity to personally speak with many of these church executives and seek their suggestions on the proposed research. Enthusiasm for the project was expressed, but the consensus of opinion was that it should be broadened to encompass the entire North Pacific Union Conference rather than the state of Oregon alone. This also was the advice of other researchers because it seemed apparent that choosing a broader geographical base would give a more representative sample of Seventhday Adventist church members. Oregon has the majority of its SDA church members concentrated in the more populated areas with nearly half of Oregon Conference church members living within a short drive of the Portland metropolitan area. The majority of the remaining members are in the Willamette Valley and southern Oregon urban areas. The urban influence factor would be greatly diffused by sampling members from all areas of the Northwest.

The next step was to meet with Union Conference church leaders. Individual meetings were arranged with the Lay Activities Secretary, the Education Secretary, and the Executive Secretary to determine if they would support such a research program. Each was very supportive and promised full cooperation. The Union Conference President had been involved in administrative duties away from Oregon, so he could not be contacted at the time of these other interviews.

When Elder Torkelsen, the Union Conference President, was again available, he was consulted about the research. He was supportive 
in his response and promised to discuss the plan with the local conference head executives at their next meeting. The researcher recelved word to progress on the research plan and to submit the research design when completed. When the design was completed, including the information-gathering instrument, it was presented to a conference regulatory committee for consideration. Each member of this committee was given a summary of the study design and a copy of the questionnaire to be used to gather the information. The research design was approved in March of 1977.

Sampling

There are approximately 50,000 Seventh-day Adventists in the North Pacific Union Conferences, a geographical area that includes Oregon, Washington, Idaho, Montana, and Alaska. This area is divided into local "conferences" as follows: Oregon: : The state of Oregon from the north to the south boundaries of the state, and from the coast on the west as far east as the Bend-Redmond area. Also included is the southwestern part of Washington as far north as Castle Rock. Washington: The remainder of the state of Washington west of the Cascade mountains. Upper Columbia: Eastern Washington, the north part of eastern Oregon and a small part of Idaho. Idaho: Remainder of that state and the south and central portion of eastern Oregon. Montana: the geographical area of the state of Montana. Alaska: The state of Alaska. For the purposes of this study it was decided to use this "conference" division as boundaries for geographical stratification. In an endeavor to keep the study from being too unwieldy, it was decided to use approximately $1 \%$ or 500 members as a sample. This 
sample was chosen randomly by computer from the North Pacific Union Conference membership lists, stratified by conferences (Oregon, Washington, Upper Columbia, Idaho, Montana, and Alaska) to assure the correct geographical ratio. Since this was a randomly selected sample not segregated by age, it was assumed that there would be a number of children included in the sample. (This was due to the lower age limits of church membership being somewhere in the neighborhood of 12 years of age.) This element was dealt with by requesting children receiving the questionnaire to give it to an adult SDA nember in their family.

\section{Questionnaire}

A questionnaire was chosen as the means of gathering information. The primary reasons being the impracticability of attempting personal interviews considering the broad geographical area included in the study.

Of prime importance to the success of the study was the gathering of data that would address the issues mentioned earlier in this description. A survey of Seventh-day Adventist literature coupled with a large number of interviews with church leaders and professionals alike indicated that these issues were of prime importance to the planning of programs to help stabilize and enrich Seventh-day Adventist families.

Input was needed from a number of professional sources to design a questionnaire that would gather the pertinent data. The professionals chosen for this input were active Seventh-day Adventists who were. attuned to Adventist lifestyle and its relationship to the issues being studied. With the assistance of the North Pacific Union 
Conference church leaders, twenty of these professionals were chosen from the fields of mental health, medicine, education, social work and the clergy. Each of these individuals was sent a rough draft of the research design and a tentative data-gathering instrument, with a request to alter the questionnaire so it would be maximumly functional in gathering the needed data.

Fifteen of the twenty professionals receiving the questionnaire and research design, responded with their suggestions. Many had obviously spent a great deal of effort, for pages of suggestions were returned, not only for content and format of the questionnaire, but suggestions on alterations in the overall research design. This assistance was invaluable in finalizing the research design and formulating the final draft of the questionnaire. While some of the professionals seemed interested in slanting the questions to their particular field (i.e. physicians added medical questions, educators were interested in adding the element of student adjustment), most suggestions adhered to the original format outline, but added a great deal of refinement and clarity.

Questionnaire Description

The final draft of the questionnaire consisted of twenty-nine questions listed on three $8 \frac{1}{2} \times 11$ inch sheets. These sheets when completed by the study participants were designed to be folded and stapled. This left exposed the return and forwarding addresses in addition to the prepaid postage making a return envelope unnecessary. (See appendix for sample.) The address preprinted for return mailing was that of the North Pacific Union Conference headquarters under the heading of 
"Family Life Study."

The computer had printed two gummed address labels for each of the members who had been randomly selected. The first set of gummed labels was used in the mailing. The remaining set was kept on file for follow-up purposes. It will be noted later that these gummed labels used in the mailing proved to be a minor problem in the mailing process.

The first page of the questionnaire consisted of a brief description of the study and its purpose. Also included were instructions on how to complete and fold the questionnaire. Participation and promptness was urged. Assurance was given that privacy would be protected by the anonymity element of the questionnaire and participants were reminded to not sign their names.

There were eight questions on the first page in addition to geographical information for stratification purposes. These questions asked for general information such as marital status, age and income categories, number of children, and number of years a Seventh-day Adventist church member.

The second page contained questions nine through eighteen. The ninth question had to do with the number of children the study participant had over sixteen years of age who were SDA church members. (Question eight was how many children under age 16 and how many over.) The purpose of this question was to get an idea of the effectiveness in terms of second generation church membership, of that particular home being studied. Most children reared in an Adventist home join that church by the age of sixteen if they plan to continue the Adventist 
way of life. The information in question eight and nine then should show fairly accurately how many second-generation members remain of those reared in SDA church families. (This would have to be compared with question five: The number of years an Adventist, and also the age of the respondent, to determine if this was indeed a Iong-term SDA family.)

Question number ten, dealing with church attendance was geared to determine if this was an active SDA family, since church attendance is considered to be of top priority among active Seventh-day Adventists.

The eleventh question gave people opportunity to rate themselves as to satisfaction with their particular life experience. Questions twelve and thirteen dealt with the issue of conflict in the home and its relationship to differences in religious belief and practice.

Questions fourteen through eighteen were inserted to gather data on attitudes toward family counseling geared to whether that participant would personally use such service if he determined it was needed. Family education and enrichment service utilization was explored in questions nineteen and twenty.

Questions twenty-one through twenty-five were designed to look at the divorce issue, both from the incidence of divorce and the utilization of counseling aspects. (Question twenty-eight gave opportunity to list factors that contributed to the marriage breakup.)

Questions twenty-six through twenty-nine were open-ended questions that were intended to give participants opportunity to discuss strengths and weaknesses of their family relationships and to suggest ways their church could provide support in strengthening 
their families and homes. In addition, it was suggested to the study participants that the back and sides of pages one and two be used for comments if the study participants so desired.

\section{Pilot Study}

In order to assure that the questionnaire was functional and that the questions would be interpreted as intended by the researchers, a pilot study was conducted. It was hoped that from this preliminary study some indication of return rate could also be established.

Participants for this primary study were hand selected from the state of Oregon to cover a broad range in education, financial, and age levels. Twenty-five questionnaires were sent out. Of these, twenty-one were returned. There were several minor changes made in the final draft as a result of the responses (i.e. instruction to turn to the next page was added to help assure that the entire questionnaire would be completed). This pilot study was also designed to assure anonymity of the participants. Both the pilot study questionnaire and the final draft that was sent to the random sample had a cover letter written by Elder M. Torklesen, Union Conference President. This letter introduced the researcher, verified church sanction of the study and urged North Pacific Union Conference church members to participate in the study. (See appendix for samples of the letters..)

The North Pacific Union Conference publishes a twice monthly 24-page magazine of church. news of local interest. The May 16 issue of this magazine, the Gleaner, carried a news item about this study. The mailing of the questionnaire was timed so that it would arrive in the homes of the members selected as a sample at approximately the 
same time as the May 16 issue of the Gleaner. It was hoped that the news item would not only inform the members of the North Pacific Union members of the study, but also be an element to encourage recipients of the questionnaire to respond. (See appendix for copy of news item.) 


\section{CHAPTER III}

\section{RESEARCH FINDINGS}

\section{Introduction}

Five hundred people were chosen by computer from the membership lists of the North Pacific Union Conference of Seventh-day Adventists as a sample for this study on Adventist family life. Each of the individuals chosen as a sample member received a questionnaire by mail.

It is estimated by the Oregon Conference Educational Department that approximately $15 \%$ of that conference's membership is made up of children between the ages of 10 and 18. Since Adventist children rarely join the church before age 10, it was also assumed that few, if any, children younger than 10 would receive the questionnaire. Because the random selection of sample members was made without age segregation, it was anticipated that some children between the ages of 10 and 18 would receive the questionnaire. Since the study was designed for adults, a note was attached to the questionnaire requesting the recipient, if a child, to give the questionnaire to an adult family member who was a Seventh-day Adventist.

The completed questionnaires that were returned to the researcher furnished the data that was used in compiling the findings that are described in this chapter. 
Response To Questionnaire

of the 500 questionnaires mailed out, approximately 40 were returned due to insufficient address, "moved address unknown," or some other factor making it undeliverable. Ten of the questionnaires were apparently refused by the addressee as they came back marked "refused." Address labels improperly attached (lost in the mailing process) caused the return of another 7 questionnaires. This made a total of 57 ( $11 \%$ ) that were not delivered by the postal system to the selected sample. It is assumed that the balance of 443 questionnaires reached the sampled respondents. The table below shows the completion rate for the questionnaires that were sent out.

TABLE I QUESTIONNAIRES MAILED TO SELECTED SAMPLE

\begin{tabular}{lcc}
\hline & $f$ & $\%$ \\
\hline Questionnaires Returned Completed & 307 & 61 \\
Questionnaires Returned Incomplete & 20 & 4 \\
Questionnaires Not Returned & 57 & 11 \\
Questionnaires Not Delivered & $\underline{116}$ & $\underline{24}$ \\
Total Questionnaires Mailed Out & 500 & 100 \\
\hline
\end{tabular}

Return Rate

The 307 completed questionnaires returned for tabulation constitute a $68.2 \%$ rate of the 443 questionnaires that actually reached sample members. It had been hoped that the return rate would be higher, but the researcher aid not take into consideration the nonactive church 
members who were found to make up a majority of the nonresponse group. If the twenty unusable returned questionnaires were included in the return rate, it would raise the rate to $72.4 \%$.

\section{Return By Geographical Areas}

While the questionnaires were anonymous, respondents were requested to indicate the name of their local church and conference. This information was needed for geographical stratification. While either church or conference information was sufficient for geographical stratification, the additional information of the local church aided in the geographical classification when the "conference" information was omitted. A few respondents failed to fill in either of these blanks. In these cases the postmark was used as geographical identification since it seemed unlikely that many of the respondents would travel outside their conference to mail the questionnaire.

Since the sample was chosen randomly in proportion to the number of church members in each of the six geographical areas, Oregon had by far the highest number of responses. (More Adventists live in Oregon than any of the other five geographical areas used in the stratification.) Alaska, however, had the highest return rate (95\%) even though questionnaires sent to that state were few in number, due to the sparse number of Adventists in the state of Alaska. The following table will show approximate conference memberships compared to return rate of the questionnaire received by sample members. 
TABLE II

NORTH PACIFIC UNION CONFERENCE MEMBERSHIP

DISTRIBUTION COMPARED TO QUESTIONNAIRES

RETURNED PER CONFERENCE

\begin{tabular}{lccc}
\hline Conference & Membership & $\begin{array}{c}\text { Number of } \\
\text { Questionnaires } \\
\text { Sent }\end{array}$ & $\begin{array}{c}\text { \% of } \\
\text { Questionnaires } \\
\text { Returned }\end{array}$ \\
\hline Oregon & 23,000 & 120 & 53 \\
Upper Columbia & 16,000 & 79 & 69 \\
Washington & 10,000 & 63 & 63 \\
Idaho & 4,000 & 18 & 60 \\
Montana & 2,500 & 17 & 71 \\
Ailaska & 1,000 & 10 & 95 \\
\hline
\end{tabular}

$\underline{\text { Return By Sex }}$

Respondents were predominately female (205), compared to 102 males responding. While accurate data on the male/female ratio among Seventh-day Adventist members was not available to the researcher, it was estimated by church officials that the ratio is approximately $60 \%$ female to $40 \%$ male within the Adventist congregations in the United States. Using these estimates, it can be assumed that approximately 270 women and 180 men received the questionnaires. It is estimated that while $76 \%$ of the women responded, only $58 \%$ of the men returned a completed questionnaire.

Nonrespondents

The nonrespondents in the sample were contacted approximately four weeks after the mailing of the questionnaires. A list of names 
and addresses of those receiving questionnaires was available, however because the questionnaires were anonymous, it was not known who had returned them to the researcher. For this reason an endeavor was made to contact by telephone everyone who had received a questionnaire in the three areas selected for this follow-up check. Sample members who indicated they had returned the completed questionnaires were thanked for their participation; those who had not were questioned as to why they had not participated.

The areas selected for this telephone follow-up were chosen for the convenience of the researcher in addition to being areas of more concentrated church membership. The areas chosen were the Portland Metropolitan area, Southern Washington, and the Northern Willamette Valley. While the purpose of the telephone interview was to determine factors involved in the interviewee not participating in the study, it was also hoped the nonrespondents could also be encouraged to participate even though the deadine for returning the completed questionnaire had passed. However, of the six questionnaires received after the telephone interviews were conducted, none were postmarked from the areas contacted by telephone.

Of the approximately 100 people contacted by telephone, 31 indicated they had not returned their questionnaires. The reasons they gave for not participating in the study are shown in the following table. 
TABLE III

REASONS FOR NONRESPONSE

Reason

No longer active church members,

do not wish to participate

Study did not apply to them

Too busy

Still intend to return

questionnaire

Total f

19

4

$5 \quad 16$

$\underline{3} \quad \underline{10}$

$31 \quad 100$

Description Of Respondents

The largest number of respondents were between ages 24 and 50 .

The table shows the number of respondents in each age category.

TABLE IV

AGES OF RESPONDENTS

BY CATEGORIES

\begin{tabular}{ccc}
\hline Age & $f$ & $\%$ \\
\hline Under 15 & 0 & 0 \\
$15-18$ & 5 & 2 \\
$19-23$ & 11 & 4 \\
$24-35$ & 88 & 29 \\
$36-50$ & 95 & 30 \\
$51-65$ & 61 & 20 \\
over 65 & 47 & 15 \\
Total & 307 & 100 \\
\hline
\end{tabular}


Marital siatus of the respondents indicate that 239 are married (not necessarily the first marriage) and the remaining 68 are single, either never married, married and divorced, widowed or separated. The number of years married indicated by the married respondents varied from newly married to 51 years. (Mean 20.816, Standard Deviation 12.735) The range for respondents' years of membership in the Seventh-day Adventist church also varied from a few months to 68 years. (Mean 22.466, Standard Deviation 14.827) 238 respondents indicated their spouse was also a SDA church member. $29(9 \%)$ of the married respondents reported that their spouse is not an Adventist.

Income ranges are broad as indicated by the table presented below.

\section{TABLE V}

INCOME IEVELS OF QUESTIONNAIRE RESPONDENTS

(Couples' Combined Income)

\begin{tabular}{lcr}
\hline & $f$ & $\%$ \\
Under $\$ 5,000$ & 55 & 18 \\
$\$ 5,000-9,999$ & 58 & 19 \\
$\$ 10,000-14,999$ & 51 & 17 \\
$\$ 15,000-19,999$ & 59 & 19 \\
$\$ 20,000-25,000$ & 23 & 7 \\
Above $\$ 25,000$ & 55 & 18 \\
\hline
\end{tabular}

The number of respondents with children under sixteen is approximately equal to those who do not have children in that age category. More than half (58\%) have children over $16.42 \%$ report they do not have children over 16. 
Data on attendance show a definite pattern of regular church attendance among the respondents as shown in the table below.

TABLE VI

CHURCH ATTENDANCE PATTERNS

OF RESPONDENTS

\begin{tabular}{lrc}
\hline & $f$ & $\%$ \\
\hline No longer attend & 5 & 2 \\
Seldom attend & 10 & 3 \\
Occasionally attend & 32 & 11 \\
Regularly attend & 256 & 84 \\
\hline
\end{tabular}

In the questionnaire, respondents were given opportunity to rate themselves on degree of happiness. This was done by using a scale of $1-5$. The wording of the question suggested satisfaction with their family life specifically rather than including vocational, social, or other general aspects of life on a whole. Most respondents rated themselves as experiencing considerable happiness in their current life experience as seen in Figure 2.

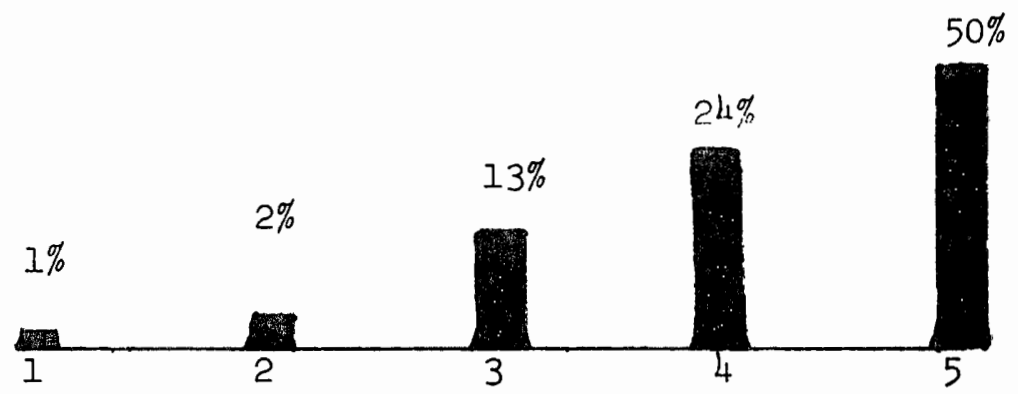

Figure 2. Degree of happiness (Scale 1-5). Degree of satisfaction with family as reported by respondents. (\% represents the number of respondents.) 
A profile of a typical respondent, using the means (averages) of the various descriptive variables, show the respondent to be female, married for 21 years, a church member for 22 years, with a Seventh-day Adventist spouse. The families composed of two children under 16 and two over that age and are living on an income of approximately $\$ 15,000$ annually. The respondent is an active church member attending church regularly and rates herself high in the degree of happiness she is enjoying in her family life.

This profile might be quite different if all questionnaires had been returned. Since more than half the nonrespondents contacted no longer attend church, a 100\% response would obviously alter attendance patterns of the profile. Because $85 \%$ of the respondents indicated they are active in church attendance, it is assumed that the data compiled from the returned questionnaires is more representative of the active SDA member rather than the complete range of Adventists from active to nonactive. (For purposes of this study, "active Adventist" is defined as one attending church services regularly.)

The next section of the research findings will center around data that primarily addresses the three issues of the study.

1. Is Religious Belief Or Practice A Major Source of Conflict In SDA Marriages

136 of the respondents indicated that they were experiencing or had experienced marital unhappiness related to difference in religious belief or commitment. Of this number 31 or $23 \%$ stated that their unhappiness was totally related to these differences. 30 or $21 \%$ indicated that it was highly related. The remaining 76 or $56 \%$ said it 
was somewhat related in varying degrees.

of the 136 saying that religious differences had brought unhappiness to their marriage, 130 or $95 \%$ indicated that the conflict was due to differences in practice rather than religious belief. The table below shows the relationship between conflict due to religious differences and sex of respondent and church membership.

TABLE VII

RESPONDENTS REPORTING RELIGIOUS CONFLICT IN THEIR MARRIAGE

\begin{tabular}{lcc}
\hline & $f$ & $\%$ \\
\hline Females & 89 & $29^{1}$ \\
Males & 47 & $15^{2}$ \\
Both spouses SDA members & 129 & $42^{3}$ \\
One spouse SDA member & 7 & $2^{3}$ \\
\hline Total female respondents & & \\
2 Total male respondents & & \\
3otal respondents & &
\end{tabular}

2. What Is The Incidence of Divorce Among SDA Members?

In the portion of the questionnaire dealing with general information, respondents were requested to indicate their marital status. $17 \%$ (52) reported that they were divorced, or divorced and remarried. However, respondents were asked in a separate question (No. 2l) if they had been through a divorce. 16\% (49) of the total respondents said they had at some time been divorced, $54 \%$ said they had never been 
divorced, but an additional $30 \%$ did not answer the question. There is no way to determine into which category those not answering should be placed. It was hoped that this figure could be used to cross-check the original marital status figure for accuracy. Due to the large number not answering the question, this figure cannot be assumed to be an accurate estimate of divorced respondents. Since $17 \%$ of the respondents did indicate they had been through a divorce at some time in their life, it can be assumed that this number represents a minimum figure. of those stating they have been through a divorce 16 (32\%) indicated it was before they became a Seventh-day Adventist church member.

Another missing element in the determination of an accurate divorce rate among Seventh-day Adventists, is that of the nonrespondent. It might be assumed that since a large number of the nonrespondents are no longer practicing Adventists that their divorce rate might well be closer to national averages. If this is so, then the divorce rate for Adventists in general might be considerably higher than the $17 \%$ of active adult Adventists the study indicates have experienced divorce. Hopefully, future studies will clarify this particular issue.

Of the group who said they had been divorced while being a member of the Seventh-day Adventist church, 50\% (17) said their spouse was not an Adventist at the time of divorce. See the following tables. 
TABLE VIII

RESPONDENT'S MEMBERSHIP STATUS

AT TIME OF DIVORCE

\begin{tabular}{lcr}
\hline & $f$ & $\%{ }^{*}$ \\
\hline $\begin{array}{l}\text { Divorced while } \\
\text { SDA member }\end{array}$ & 35 & 69 \\
$\begin{array}{l}\text { Divorced before } \\
\text { becoming SDA member }\end{array}$ & 16 & 30 \\
\hline $\begin{array}{l}\text { *\% represent total reporting they had } \\
\text { been divorced. }\end{array}$ & & \\
\end{tabular}

TABLE IX

SPOUSE MEMBERSHIP STATUS FOR

MEMBERS DIVORCED WHILE

SDA MEMBER

\begin{tabular}{lcr}
\hline & $f$ & $\%^{*}$ \\
\hline $\begin{array}{l}\text { Spouse SDA } \\
\text { Time of divorce }\end{array}$ & 18 & 51 \\
$\begin{array}{l}\text { Spouse nonmember } \\
\text { Time of divorce }\end{array}$ & 17 & 49 \\
\hline *\% represents total reporting they \\
were divorced while SDA member.
\end{tabular}

The researcher is aware that the figures in the tables above are incomplete and are not an accurate picture of divorce in the general SDA membership. However, of those indicating they have been divorced (both while and before becoming an SDA), one-third of these divorces occur among families where both spouses were Seventh-day Adventist members at the time of the divorce. 
3. Do Seventh-day Adventists See

Themselves As Needing Marital/Family

Services? Would They Utilize Such

Services If Available from SDA

Professionals?

The findings addressing this issue will be divided into two

categories. The first will concern whether Adventists see themselves as needing marital/family services.

As previously pointed out, $17 \%$ of the respondents have been involved in divorce. Nearly two-thirds of that number indicated the breakup of the home occurred while they were SDA church members. More than one-half indicated counseling might have been helpful at that time. (See table below.)

TABLE $X$

DIVORCED RESPONDENTS' ATTITUDES

TOWARD COUNSELING

\begin{tabular}{lcc}
\hline & $f$ & $\%^{*}$ \\
\hline Would have been helpful & 9 & 18 \\
"Might" have been helpful & 18 & 36 \\
Would lot have been helpfil. & 24 & 48
\end{tabular}

*\% equals total number divorced.

$20 \%$ (61) of all the respondents when asked if they had ever had marital counseling said they had had some type of marital counseling during their married life. This would indicate these individuals had experienced a need as they saw it for counseling.

Nearly half of all the respondents indicated they had experienced unhappiness due to religious conflict in their marriage. The 
questionnaire was not designed to try to measure severity of this conflict or whether respondents saw this as a need for professional counseling service, however, it was stated by the respondents that this conflict brought unhappiness to their relationship.

In the open-ended section of the questionnaire, nearly $70 \%$ of all respondents listed factors that were bringing (or had brought) them unhappiness in the past. There were nine major categories into which the factors were grouped, as follows: Poor communication, criticism, power struggles, poor health, problems with in-laws, children, finances, sex and incompatibility. The table below shows how sample members responded to this question by rank. Their answers were grouped into categories at the discretion of the researcher. Some respondents listed more than one problem category. In such cases, all categories listed by respondent were tabulated.

TABLE XI

PROBLEM AREAS IN MARRIAGE RELATIONSHIP

AS REPORTED BY RESPONDENTS (BY RANK)

1. Incompatibility

2. Sexual Problems

3. Financial.

4. Poor Communication

5. Children

6. In-laws

7. Power Struggle

8. Criticism

9. Poor Health

Each of the above categories listed as sources of friction in the marriage, with perhaps the exception of the last, are areas most professional counselors deal with extensively in counseling sessions. Again this response indicates a possible need for counseling services among Seventh-day Adventists. 
Another open-ended question gave respondents opportunity to make suggestions as to ways their (SDA) church could support and strengthen their home-marital life. The majority of suggestions made by the respondents seemed to indicate a need, although many of the suggestions could not be classified "social or family services." These suggestions were grouped into four categories with eleven entries. While only three of the entries related directly to family social services, these three entries, "Counseling Services by SDA Christian Professionals," "Classes Conducted by SDA Professionals in Family Life," and "Pastors With Special Training in Family Life," made up nearly 90 or $40 \%$ of the suggestions. The eleven entries in the four categories and the number of times they were suggested is shown in the table below.

TABLE XII

RESPONDENTS' SUGGESTIONS ON HOW THEIR CHURCH COULD HELP ENRICH OR STRENGTHEN THEIR FAMILY LIFE

Family Life-SDA Professional Involvement

Classes

Counseling Service

Pastors With Specialization in Family Life

Religious Life

Increased Spiritual Emphasis

Fellowship and Social Interaction

Increase in Church-sponsored Social Activities 33

More Personalized Attention

Miscellaneous

Less Church Work

Smaller Churches

Cut Educational Costs

Don't Know How Church Could Help 
The second part of the issue on Adventists' need and utilization addresses the question: Would Adventists use family/marital services if/when available? This is partially answered in the date from the question asking if respondents had ever had counseling and if so, from what source. The table below indicates the answers from the respondents.

TABLE XIII

SOURCE OF MARITAL COUNSELING

RECEIVED BY RESPONDENTS

\begin{tabular}{lrr}
\hline & $f$ & $\%$ \\
\hline With Pastor & 35 & 11 \\
With Doctor & 6 & 2 \\
Professional Counselor & 24 & 8 \\
No Counseling & 243 & 79 \\
\hline
\end{tabular}

Since $20 \%$ of all respondents have had some type of marital counseling either with pastor, doctor or a professional marriage counselor, it would appear that at least one-fifth of all Seventh-day Adventists have actively sought out help for marital problems. However, $11 \%$ of these counseled with their pastors which usually means the "Counselor" had limited formal training in marriage counseling.

Respondents were also asked if they would use family counseling for problems. $48 \%$ answered in the affirmative, with an additional $18 \%$ indicating they were undecided. $11 \%$ stated they needed more information before making a decision: Only 15\% stated they would not use family/marital counseling for their problems. 
The table below shows the preference of the respondents regarding from whom they would prefer counseling.

TABLE XIV

TYPE OF COUNSELORS PREFERRED

BY RESPONDENTS

\begin{tabular}{lr}
\hline & $f$ \\
\hline Pastor With Special Training in Family Life & 138 \\
Professional Marriage Counselor & \\
(Psychologist or Social Worker) & 110 \\
Family Doctor & 47 \\
\hline
\end{tabular}

The table below shows the reasons given by those stating they would not use services.

TABLE XV

RESPONDENTS' REASONS FOR NONUTILIZATION

OF COUNSELING SERVICES

\begin{tabular}{llr}
\hline & $f$ & \%* $^{*}$ \\
\hline Do Not Believe in Professional Counseling & 46 & 15 \\
Services Not Available & 21 & 7 \\
Could Not Help Problem & 15 & 5 \\
Could Not Afford Services & 12 & 4 \\
Do Not Know Where To Go For Help & 21 & 7 \\
Afraid Who Might Find Out . & 15 & 5 \\
\hline *\% of total study group. & & \\
\hline
\end{tabular}


Another question related to utilization of services was the question that asked if the study participant would attend marriage/family seminars, workshops or retreats to bring enrichment to their family Iife. The answers are shown in the table below.

TABIE XVI

RESPONDENTTS' ATTITUDES TOWARD FAMILY ENRICHMENT PROGRAMS

\begin{tabular}{lcc}
\hline & f & \%* \\
\hline Would Attend & 114 & 37 \\
Would Not Attend & 55 & 18 \\
Need More Information & 69 & 22 \\
Did Not Respond To Question & 69 & 22 \\
\hline
\end{tabular}

*Percentages are of the total study respondents.

Of the 55 answering why they would not attend such educational functions, 23 said they had no need of enrichment, 11 said it could not help them, 4 were not interested, 4 would have babysitting problems, and 13 said none was offered in their area.

The above data indicates that more than half of all respondents might be interested in marriage enrichment programs if offered.

Related Questions

There were several questions included in the questionnaire intended to gather information that church officials felt would be useful. Such data gathering was limited, however, to some area of family life, even though it might not be an issue under study. 
One of these related questions had to do with issues divorced respondents felt were major contributing factors to the breakup of their marriage. It was not the purpose of this research to study indepth the question of divorce in the Adventist church, but rather to get a more accurate picture of its frequency. However, respondents were given opportunity to list the major factors as they saw them in the disintegration of their marriage. It was hoped that this information, even though general in nature, might aid in a better understanding of this subject. The format of the question was open ended, with the responses, by rank, being listed in the table below.

TABLE XVII

TOP FIVE MAJOR FACTORS IN MARRIAGE BREAKUP AS LISTED BY DTVORCED RESPONDENTS (BY RANK)

\begin{tabular}{ll} 
1. Adultery \\
2. Immaturity \\
3. Sexual Probiems \\
4. Step-children \\
5. Drinking \\
\hline
\end{tabular}

It had been hoped that data gathered in questions eight and nine would show fairly accurately the number of children remaining members of the SDA church who have been reared by Adventist parents. However, it was discovered that due to the design of the questions and the number of the variables involved there would be considerable technical. difficulty in arriving at that answer. Because of these difficulties and since this was not a main issue of this research, this question will not be further dealt with in this study. 
Data on the relationship of church attendance to satisfaction in family, and also the relationship of attendance to religious conflict in marriage was also requested by church officials. The tables below show these comparisons.

TABLE XVIII

SATISFACTION IN FAMILY LIFE COMPARED TO CHURCH ATTENDANCE PATTERNS

\begin{tabular}{lccccccc}
\hline & $f$ & $\%$ & $f$ & $\%$ & $f$ & $\%$ \\
\hline & $\begin{array}{l}\text { Seldom } \\
\text { Happy }\end{array}$ & & $\begin{array}{l}\text { Happy Part } \\
\text { Of The Time }\end{array}$ & $\begin{array}{c}\text { Usually } \\
\text { Happy }\end{array}$ \\
Attend Church Regularly & 26 & 10 & 32 & 13 & 198 & 77 \\
$\begin{array}{l}\text { Never, Seldom, Or } \\
\text { Occasionally Attend }\end{array}$ & 2 & 4 & 6 & 13 & 32 & 68 \\
\begin{tabular}{l} 
Church \\
\hline
\end{tabular} & 26 & & & & & & \\
\hline
\end{tabular}

Note: For this data to be meaningful, the percentages must indicate the number of respondents in the two attendance categories rather than total respondents.

TABLE XIX

CHURCH ATTENDANCE COMPARED TO RELIGIOUS CONFLICT IN THE HOME

\begin{tabular}{|c|c|c|c|c|c|c|}
\hline & & & $f$ & $\%$ & $f$ & $\%$ \\
\hline & $\begin{array}{l}\text { Conf } \\
\text { Unre } \\
\text { To Re } \\
\end{array}$ & $\begin{array}{l}\text { ct } \\
\text { ted } \\
\text { gion }\end{array}$ & $\begin{array}{r}\text { Con } \\
\text { Par } \\
\text { Rela } \\
\text { Rel } \\
\end{array}$ & $\begin{array}{l}\text { ct } \\
\text { liy } \\
\text { to } \\
\text { on } \\
\end{array}$ & $\begin{array}{r}\mathrm{Cc} \\
\mathrm{T} c \\
\mathrm{Re} \\
\mathrm{Re} \\
\end{array}$ & $\begin{array}{l}\text { lict } \\
\text { liy } \\
\text { d to } \\
\text { ion }\end{array}$ \\
\hline Attend Church Regularly & 137 & 53 & 115 & 45 & 4 & 2 \\
\hline $\begin{array}{l}\text { Never, Seldom or } \\
\text { Occasionally Attend } \\
\text { Church }\end{array}$ & 32 & 70 & 12 & 26 & 2 & 4 \\
\hline
\end{tabular}


One other open-ended question was included in the questionnaire to gather data on family life to aid in planning enrichment programs for SDA members. In this question respondents were asked to list the major strength in their marriage. Some questionnaires had more than one strength listed. In such cases all listings were tabulated and were put into categories as follows: These categories are ranked. The percentages shown are representing the percent of the total number of respondents answering this question.

TABLE XX

REPORTED STRENGTHS IN

MARRIAGE (BY RANK)

\begin{tabular}{lr}
\hline & $\%$ \\
\hline 1. Religious Belief & 27 \\
2. Companionship & 26 \\
3. Love & 20 \\
4. Shared Goals & 14 \\
5. Children & 8 \\
5. Miscellaneous & 2 \\
7. No Strengths & 1 \\
\hline
\end{tabular}

The above table completes the description of the findings. The remainder of the paper will deal with conclusions drawn from the data collected, along with recommendations for dealing with the research issues. 
CHAPTER IV

CONCLUSIONS AND RECOMMENDATIONS

Introduction

This study initially began from interest in the quality of family life of members following the Seventh-day Adventist lifestyle, along with attitudes that influence family interaction. Seventh-day Adventists are known to be a conservative group of Christians, whose religious belief strongly influences the lifestyle of the majority of its members. Among the beliefs that make Adventists different from the general pubIic is their belief in the 7 th day of the week (Saturday) to be a holy day of worship. On this day most Adventists abstain from secular activities, (work, business and many forms of recreation) to devote themselves to worship and religious activities.

Adventists' view of health also affects their lifestyle making them "different" from many of the other residents in their communities. Most SDA's do not smoke, drink alcoholic beverages, or believe in unmarried sexual activities. The majority are vegetarians and place an emphasis on natural foods.

These beliefs in addition to their educational system and fundamental intexpretation of the Bible, often separate the Adventists from close interaction with nonmembers. This study indicates that only $12 \%$ of respondents were married to nonmembers. It is likely that of that number many had joined the church following their marriage. These figures suggest that the majority of SDA members marry within the church. 
Professionals in the helping fields suggest that Seventh-day Adventists on the whole do not readily utilize community services related to mental health and various family services. If this is true, the question immediately arises as to whether Adventists are having problems in interpersonal relationships. Conversations with church leaders of the Seventh-day Adventist faith, their clergy, and the general church membership seems to indicate these people feel there are problems. Cited as evidence is the more frequent breakup of marriages, incidence of unmarried pregnancy, extramarital affairs, teenage delinquency problems, drug use and other symptoms of unrest and dissatisfaction. While clergy say increasing numbers of their parishioners are exhibiting symptoms of trouble in their home, little research has ever been done to document incidence of such problems. However, pastors do indicate they have more call for counseling services from church congregations currently than in years past. ${ }^{15}$

If it can be assumed that Seventh-day Adventists do not readily use conmunity services for marital and mental health counseling needs but they do indeed have these problems, there must be some other barrier to their obtaining these services. This researcher suggests that there is indeed a barrier, and this barriex has to do with unavailability of Seventh-day Adventist professional counseling services in many areas. The conclusions will show there is a need for marital counseling services, and that Seventh-day Adventists would utilize such services if the professionals rendering these services were also

${ }^{15}$ Statement made by Rankin Wentland, Vice-president of the Oregon Conference of Seventh-day Adventists. 
Seventh-day Adventists. The nature of many of the problems in Adventist marriages in addition to the philosophical viewpoint of the majority of Adventists does create a barrier to utilization of the services offered by most communities.

Because of the conservative lifestyle of Seventh-day Adventists, it is assumed that the family problems would occur far less frequently than national averages. However, this has not been established through research.

Due to the magnitude of the possibility for research on this subject, it was decided that this study would be limited to the following three questions: (1) What is the incidence of divorce among SDA members? (2) Is religious belief or practice a major source of conflict in SDA marriages? (3) Do Seventh-day Adventists see themselves as needing marital/family services?. Would they utilize such services if available?

This chapter will deal with the conclusions drawn from the data that was collected from 307 questionnaires returned by randomly selected Seventh-day Adventists from the North Pacific Union Conference.

It was apparent by the responses that the majority of Seventh-day Adventists have a great deal of interest in the quality of Seventh-day Adventist homes. The attitudes expressed by respondents on the openended questions included on the questionnaire and the large number of questionnaires that had written comments on the reverse sides of the pages suggested an overall enthusiasm for the study. Many questionnaires were returned with the reverse sides of page one and two completely filled with comments on the current programs conducted by the 
church for families, personal needs of the respondents, and many personal experiences cited to illustrate a particular point being made by the respondent. The need to "ventilate" seemed apparent in many responses. The anonymous quality of the questionnaire appeared to motivate many to "share" sensitive areas in their family life that according to the respondent they never discussed with others.

The attitudes of the nonrespondents according to the telephone follow-up seemed to indicate a number of nonactive Adventist members who no longer felt an attachment to the church and its programs. Some of these individuals also indicate serious problems in their families for which they were unable to find solutions. The researcher sensed a feeling of hopelessness among these inactive SDA members.

Response of Sample Members

Response from the six geographical areas was fairly consistent. However, Alaska and Montana had a higher response rate than the other conferences.

The Seventh-day Adventist data bank does not have figures available that show age, sex, income, number of children and other information on each Seventh-day Adventist listed in membership files. Since the sample in this study appears to be geographically representative of the entire membership of the North Pacific Union, it is assumed that it is also representative in the other variables of age, income, marital status and other descriptive data requested on the questionnaire. However, the higher response from female members in relationship to estimated membership ratios suggest a slight female bias. This bias was expected because of the subject matter of the study. (It seems to be the 
popular opinion that women are more interested in the subject of home and family than men.)

Divorce Among Seventh-day Adventists

The marital status information obtained was important to one of the issues of the research project, that of determining the rate of divorce among Seventh-day Adventist church members. Due to the nonresponse factor an accurate divorce rate could not be established. However, $17 \%$ of the respondents did indicate they had been divorced and this could be viewed as a minimum figure for a divorce rate. The Carscallen study on the divorce rate of Seventh-day Adventists in the Upper Columbia Conference, (one of the conferences also involved in this study) indicated the following: Among 66 churches studied in the Upper Columbia Conference, during the year of 1976 there were 187 marriages reported. During the same period among the same churches there were 37 divorces reported. The number of divorces compare to the marriages in the period studied was $19.78 \%$. Figures from the Carscallen study do not indicate if both partners in the marriages and the divorces cited were Seventh-Jay Adventist church members. Mrs. Carscellan states that she was unable to obtain statistics previously gathered on Adventist divorce rate needed for research she was doing in her doctoral program, so she obtained permission to do the brief study in Upper. Columbia to supply. some of the data needed for her study.

The Carscallen study cannot be used as a direct comparison with research findings on divorce in this study. (The number of divorces compared to marriage in a given period is quite different information from the number of respondents reporting they had been divorced at 
some time.) The Carscallen study, however, is relevant to this study in that it adds one other dimension to what is known of the incidence of divorce among Seventh-day Adventists, in the North Pacific Union Conference.

The research being conducted by Dr. Conrad Reichert at Andrews University in Michigan will also supply more data on the divorce rate. With continuing research in this area, hopefully a truer picture of this factor in Adventist families can be determined. Accurate information in this area may redirect the emphasis church leaders are placing at this time in the voerall church program. At the same time data is gathered on the divorce rate among Adventists it would be advisable to endeavor to gauge the quality of Adventist marriages, which are the foundation of Adventist homes. A low divorce rate does not necessarily guarantee the marriages that remain intact are stable and satisfying to the people involved. Since the home is of such importance in the development of balanced functional people, it would seem imperative to the perpetuation of quality Adventist lifestyle that steps be taken in strengthening and upgrading the quality of Adventist homes. According to the national divorce rate it is estimated that one out of every three first marriages will end in divorces. 16 While this may vary between geographical regions, the Pacific Northwest rates above the mean in ranking of states on divorce rate. The data gathered in this study, while probably not a completely accurate picture of incidence of divorce among Adventists, does suggest that the divorce rate for 16 Encyclopedia of Social Work 17 th Edition (New York, National Association of Social Workers, 1977) Vol. 1, p. 373. 
Adventists is well below national averages.

While it was not the purpose of this study to determine the variables that led to divorce among Adventists, the open-ended questions did give some opportunity for this type of response. One such question was "What factors other than religious conflict led to the breakup of your home?" In response adultery was ranked first by respondents as the reason for the breakup of their marriage. This would indicate that many Adventists continue to abide by the Biblical sanction of divorce for adultery only. This doctrine continues to be upheld by the SDA church to this day. Following closely in second place in the factors listed by respondents as the cause of their divorce is immaturity and the third most mentioned factor was problems related to sex. It was an assumption of the researcher that religious conflict would be a prime factor in divorce, but this did not prove to be true, even though half of the respondents stating they had been divorced also said their spouses were not SDA church members at the time of divorce. (See section on Religious Conflict In Marriage.)

Another open-ended question geared to gather information on sources of unhappiness among Adventist families still intact show incompatibility to rank first, followed closely by sexual problems. (Incompatibility might also include sexual problems since there seems to be a close relationship in these variables.)

Since the issues in the study were not sexual in nature, the researcher deliberately did not gear any questions to the intimate area of family life. However, the spontaneous responses yielded information indicating many problems in this area. Homosexuality, both male and 
female, was referred to a number of times. The subject of unmarried pregnancy, and abortions for both the married and unmarried came to the front. The problems surrounding the issue of premarital and extramarital sex are being faced by some Adventist members. These are not only abstract "conversation pieces" found in many school dormitories or discreetly referred to in the pastor's sermon, but are problems faced often by Seventh-day Adventists.

An illustration would be the church officer, who wrote that she was also a lesbian, torn by the conflict of her perception of right and wrong, and her inability to gain control of her physical needs. Her question was:

I cannot consult with my doctor about this matter, he is a church elder in my church. If my sexual preference were known among the rest of the church membership, even though I may not be actively following that preference, I would most surely be disfellowship. I cannot discuss this with my pastor, and most assuredly not with any of the good church 'sisters.' I cannot find Adventist literature on this subject, and much of the other literature justifies my position. I gain spiritual guidance from devotions, but feel the need of an understanding human for support. Where do I go? 17

This respondent's plight brings to mind the question, "How many others, both marrieu and unmarried, have problems involving the sexual roles with nowhere to turn for help from another human being?" Perhaps a better understanding of human sexuality would aid the young people that will be tomorrow's adult Seventh-day Adventists to deal more effectively with many kinds of sexual problems that may face them as they gain adulthood.

Classes in family life and human sexuality have not had strong

17 Details changed to protect privacy. 
emphasis in Seventh-day Adventist schools, regardless of grade level. In recent years more courses in the secondary level through college have been geared to some areas of family life, but few deal with the more intimate aspects of marriage. Those that do often are taught from a "biological" base rather than dealing with the interpersonal relationships involved. According to the data found in the study, it would seem advisable to give study to incorporating such subject matter into the curriculum of all grade levels. It would be important that such material be presented factually rather than idealistically, but much wisdom would be needed to create a program that would benefit the student in his life experience, and yet be acceptable to both parents and church leaders. This study's findings suggest that sex plays a tremendously important part in both the success and failure of Adventist marriages. Adventists are, however, beginning to move in the direction of endeavoring to better understand the sexual problems of their members. This is illustrated by a workshop to be held this spring at Andrews University dealing with adolescent sexuality. Hopefully the focus will be on the specific needs of SDA youth.

Other areas contributing to marital unhappiness as mentioned by divorced respondents are problems with step-children and drinking. Several respondents adding comments on their situations mentioned the problems they had or were encountering with their spouse's offspring from a previous marriage. One respondent commented,

Our life is one big tragic circus with the problems we are having with her kids, my kids, our kids, and the extra parents, from the previous marriages and remarriages and all the grandparents involved. Our problems wouldn't be so big if the children were not shifted from one set of parents to another, but they have their legal visitation rights. 
Problems brought about by drinking was the fifth in rank order of factors leading to breakup of marriages as listed by the respondents. Since Adventist doctrine so strongly restricts consumption of alcoholic beverages, it is unlikely SDA members would drink openly . Therefore it would probably be difficult to document the extent of drinking among SDA members. The frequency with which it was listed as the major factor in divorce was only $12 \%$ of those reporting they had been divorced. Considering that many of these people had been divorced before becoming SDA members, and approximately half of the spouses of the total number of divorced SDA members were not SDA, it may be that divorces resulting from drinking problems could have been accounted for in the non-SDA member group. If this is a correct assumption, it may be concluded that drinking problems occur rarely as a factor in SDA divorce where both partners are Adventist members. However, the subject of the "hidden drinker" as related to the Adventist church could provide an area for future study.

The above discussed five major factors leading to divorce as stated by divorced respondents were those listed other than religious conflict. The next section will deal with religious conflict in the home.

Religious Conflict In Marriage

Nearly one-half of all respondents in this study indicate they are having enough religious conflict in their marriages to bring unhappiness. The divorce figures show that for the most part this conflict is not severe enough to bring about a permanent separation, but it is bringing unhappiness to many Adventist homes. The study was not 
designed to pinpoint the conflict as to whether it was related to financial giving patterns, Sabbath observance, or Adventist schools versus public schools for offspring, or some other area of Adventist life. However, the study did establish that this conflict is overwhelmingly associated with practice rather than belief. (95\% indicated conflict was related to religious practice.) While the degree of unhappiness in the home brought about by this conflict is not known, over $50 \%$ stated that unhappiness in their home was highly related to religious conflict. (23\% stated that their unhappiness was totally related to this conflict.)

Sex of the respondent does not seem to be a factor in whether or not they are experiencing religious conflict. $46 \%$ of all male respondents reported religious conflict in their marriages, while $43 \%$ of all women respondents also reported that type of conflict. The surprising element in these figures is that only 7 or $2.5 \%$ of the total respondents reported religious conflict in the families (where spouses are not SDA members). Since 29 respondents reported non-Adventist spouses, 22 couples did not report experiencing religious conflict. It would seem likely that there would be more families with one spouse a non-SDA, if more of the nonactive members of the church were represented in the study. If this is so, it would follow the religious conflict figures might also be quite different. However, from the findings we must conclude that religious conflict is most often present in homes where both spouses are members of the Seventh-day Adventist church.

The data in this research clearly shows that the conflict is most related to practice rather than belief. This may be partially explained 
by the Adventist lifestyle that is described by many as being ultra conservative. Many of the Adventist doctrines ${ }^{18}$ relate directly to religious practice, in everyday life, thus a belief in these doctrines (and living by that belief) automatically establishes a style of life. Considering possible differences in background and upbringing of marriage partners, in addition to individual interpretation of application of church doctrine, differences of opinion between spouses is not surprising. Adding the element of individual commitment to the religious belief of the marriage partners, it is no wonder that religious differences exist in Adventist homes.

This conflict appears to have a direct relationship to church attendance. By correlating religious conflict with church attendance, we see that $47 \%$ of those attending church regularly are experiencing conflict partially or totally related to religion, while only $30 \%$ of those only occasionally, seldom or never attend are experiencing religious conflict. This suggests that those who no longer attend church do not find religion as important an issue of conflict in their home as do those who attend regularly. (It is the opinion of the researcher that with the decrease in the importance of religion in the home, there is comparable decrease in the conflict surrounding religion.) Differences of opinion may add many positive elements to a family, by bringing in potential for intellectual growth, and opportunity for expanded experience through new ideas. However, when those differences bring conflict which creates unhappiness, the differences can be very

${ }^{18}$ See SDA Church Manual on Tithing, Use of Alcoholic Beverages, Tobacco, and Sabbath observance. 
destructive to much that is positive in marriage. The frequency of respondents that reported religious conflict in their home would indicate this to be a major source of unhappiness in Seventh-day Adventist families.

Future research should endeavor to pinpoint specific areas of religious conflict between marriage partners, and try to determine to what degree this conflict is eroding marital satisfaction in Adventist marriage. It is only with knowledge of specific trouble spots in Adventist marriages that preventative and remedial programs can be developed that will be effective in stabilizing these marriages. It seems evident that since this conflict is religious in nature, church pastors have a vital role in implementing programs that are not only spiritual in nature but are also directly related to issues that are bringing this religious conflict to SDA families.

Classes such as the Home and Family series brought to Adventists in the North Pacific Union Conference in the summer of 1977, by Dr. and Mrs. Holbrook, cover topics that deal with potential conflict in Adventist homes. Since these were presented at annual conventions of Adventists, large numbers ${ }^{19}$ were exposed to the class content. However, there were many church members not able to attend these classes. Small local groups following a similar class outline would be a means of reaching many more church members interested in upgrading their marriages. In addition, individual counselors should be available, at least in areas of concentrated church membership, that could meet with individual couples to work with their particular problems.

${ }^{19}$ The Oregon Camp meeting classes were attended by several hundred. 
As indicated by study members' response to preference for marital counselor, most respondents (138) indicated they preferred pastors with special training in family life. Next most frequent choice of counselor preference was the psychologist or social worker/professional counselor. 710 respondents indicated this preference. Since religious conflict is a big issue in Adventist marriages it seems appropriate that the most preferred counselor be a pastor. However, respondents made it very clear that the pastors should have special training in interpersonal relationships related to the family. This indicates that respondents were concerned with more than basic spiritual counseling, which is the expertise of many pastors. Rather, practical tools to use in helping them solve their particular problems was indicated as a need by many respondents. At the same time, respondents were saying they preferred this counseling to be from a pastor, again indicating the preference for spiritual guidance also. $60 \%$ of the respondents that did not indicate pastor preference stated that it was important to them that their counselor be of their religious faith, which suggests that even though 110 preferred counselors that were not pastors, more than 50 of them wanted counselors of their faith. Respondents seem to feel that marriage counselors not of the Adventist faith would be less effective in dealing with marriage partner's problems, especially those related to religious conflict.

Need For Seventh-day Adventist Family And Marital Services

The two previously discussed issues, that of divorce and religious conflict within Adventist families, indicates a real need for services in these areas. The "unknown" divorce rate in the Seventh-day 
Adventist church while it is probably considerably less than national averages, is high enough to be a cause for concern. This research has not looked at the residual problems of divorce, such as problems faced by single parents, depression that often afflicts people following emotional trauma such as divorce, and the stigma especially present in the conservative element. All of these problems suggest a need for professional services.

In addition to issues of religious conflict and divorce, are sexual problems that the research found to be a source of unhappiness for many Adventists. Future research will no doubt bring to light some other areas of marital unhappiness in Adventist families. There seems to be no question that there is a definite need for family/marital services among Seventh-day Adventists. However, there may be a question as to whether all Seventh-day Adventists would utilize services if available to them.

Possible Utilization of SDA Professional Services

The findings suggest that the majority of Adventists do prefer to receive family services from SDA professionals. While pastors with special training in family counseling heads the list in preference, $36 \%$ of all respondents indicated they preferred a professional other than a pastor. Many of the respondents felt very strongly that the majority of pastors serving the churches in the North Pacific Union were not properly trained to be counseling marriage partners with complex marital problems. Several respondents cited personal experience to "illustrate" what they saw as evidence of inadequacy in counseling they had 
received from their pastors. Many others stated they would not bring personal problems to their pastor because of the lack of objectivity due to close association with the pastor through church activity. Others stated it was this close association that made a "professional" relationship impossible. One woman respondent described her feelings by saying, "Discussing my personal marital problems with the pastor would be like having a physical examination from a doctor who was a close personal friend seen regularly on a social basis. I couldn't be comfortable having someone that close know that much about me personally." Some were concerned about the confidentiality factor of discussing personal problems with the pastor. The other most commonly cited factor for not seeking help from the pastor for marital problems was the time limitation. One respondent summed it up this way, "Our pastor has two fairly large churches and no assistant. His time is taken up with administrative duties, marrying and burying, chairing numerous committees, preaching each week and conducting prayer meetings in addition to evangelistic meetings. He just wouldn't have time to listen to our problems." Apparently quite a few respondents feel most pastors do not have adequate time to deal with the personal problems of their parishoners. Even considering the disadvantages of counseling with their pastors, nearly onehalf of all respondents said they would prefer counseling with a pastor, who was specially trained.

Other attitudes shown by respondents included approximately 15\% of all respondents who said problems should not be shared with anyone but God. They felt that most problems originate with spiritual problems, therefore by straightening out the spiritual life, other problems would 
also be resolved. It was not determined by the researcher if there was an age trend in this particular group of respondents.

Nearly one-half of all respondents said they would definitely utilize family services. (Most qualified this by saying if they were given by SDA professionals and were geographically available to them.) Another 19\% said they needed more information about such services in order to make a decision to utilize family/marital services.

Nearly. one-fifth of all respondents stated they had sought marital counseling at some time in their marriage. This would suggest that a large number of Adventists are actively seeking help with troubled marriages. No data is available as to how many others would have sought help if church-related counseling had been available to them.

This research data clearly shows a need for Seventh-day Adventist counselors, whether they be pastors with specific training in marriage counseling, or other Seventh-day Adventist professionals trained in this area. The data also shows that Seventh-day Adventists indicate they would indeed use such services if available. From these findings it can be concluded that Seventh-day Adventist colleges and universities have a responsibility to offer curriculums that will prepare SDA professionals if the needs of Seventh-day Adventists are to be met. Among the conclusions drawn from this study are the following: Divorce, while occurring less frequently than national averages, is currently breaking up many Seventh-day Adventist homes. Adultery appears to be a major contributing factor in this breakup.

Religious conflict is a source of unhappiness in nearly one-half of all Adventist homes, though not severe enough in most cases to cause the home to dissolve. 
Seventh-day Adventists do need and would utilize professional services for family and marital problems. However, the preference is for these professionals to be Seventh-day Adventist. The above conclusions raise many issues that no doubt need more research before effective answers can be found for all the problems posed. It is hoped, however, the findings in this research provide direction for planning future church programs for strengthening and enriching Seventh-day Adventist homes. 

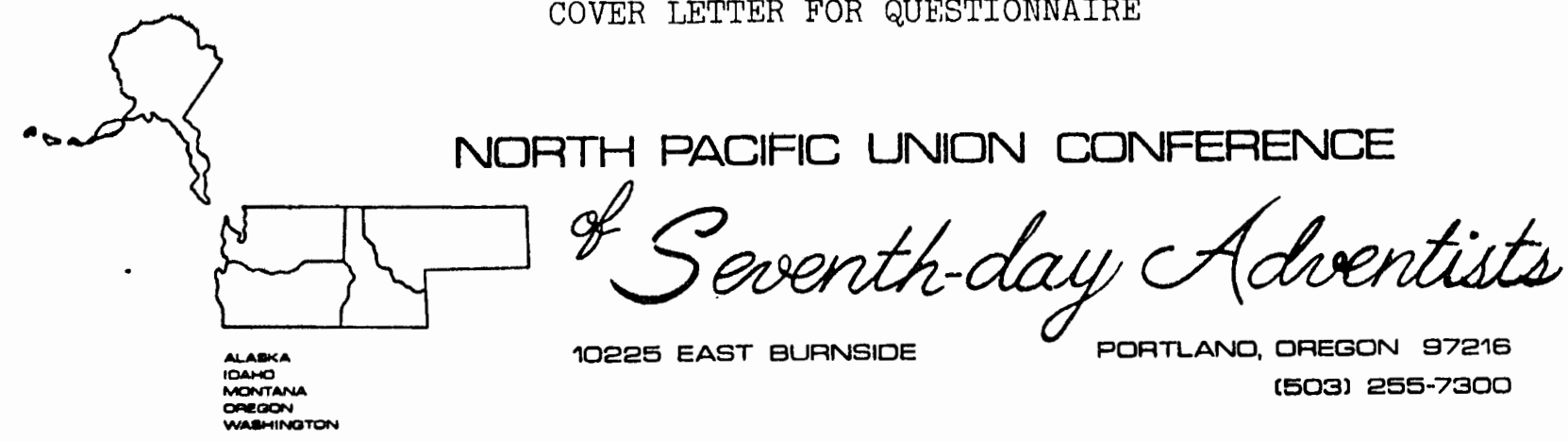

DFFICE DF THE PRESIDENT

May 1977

To a randomly selected group of Seventh-day Adventists within the North Pacific Union Conference:

This letter is to introduce Mrs. Fern Ringering of the Portland area, who is a graduate student at Portland State University.

She is presently engaged in a major study which will attempt to isolate problem areas of family relationships, as well as discover some of the positive benefiss of religious and Christian principles within the home.

The complexities of our modern society has its affect on Christian and non-Christian households alike. Hopefully this study might be helpful to the Church as we develop plans and programs designed to strengthen the Seventh-day Adventist home.

We encourage your participation in this study.

Sincerely,

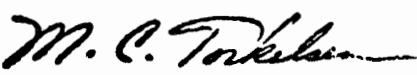

M. C. Torkelsen

PRESIDENT 
APPENDIX B

FAMILY LIFE SURVEY

Church:

Conf:

You are being asked to participate in a study on family life being conducted in the North Pacific Union Conference. The information on this questionnaire is confidential and anonymous so please be frank and open in your responses. PLEASE DO NOT PUT YOUR NAME ON THE QUESTIONNAIRE. We ask you to indicate the name of your church and conference only. Please read each question carefully, then mark the box that seems to answer the question best for you. If the question does not apply to your situation, please mark through it. Fill out the questionnaire by yourself so it will reflect your individual situation. You may make comments if you wish beneath the questions or on the back of the first two pages. When you have completed the questionnaire, please fold and mail. Postage is prepaid.

The strength of the home is of vital importance to not only the individual family members and their ability to deal with life, but the effectiveness of the church depends greatly on the quality of the homes from which its members come. Your cooperation in this study can aid in developing programs to help meet the needs of the Seventh-day Adventist families. In order for the information gathered in this sample to be representative of all the North Pacific Union members, it is important 
that each member receiving a questionnaire complete it and return it promptly. PLEASE RETURN THE COMPLETED QUESTIONNAIRE WITHIN 2 WEEKS. Thank you for your participation.

1. Sex: ( ) Male ( ) Female

2. Age: ( ) under 15 ( ) 15-18 ( ) 19-23 ( ) 24-35

$$
\text { ( ) } 36-50 \quad \text { (.) } 51-65 \text { ( ) over } 65
$$

3. Marital status: ( ) married ( ) never married ( ) divorced ( ) widowed ( ) divorced remarried ( ) widowed remarried ( ) separated

4. How many years married in present marriage? Former

5. How many years SDA Church member?

6. IF married, is spouse a SDA Church member? ( ) yes ( ) no

7. Income level: ( ) under $\$ 5,000$

(If married, ( ) \$5,000-\$9,999

couple's to- ( ) \$10,000-\$14,999

( ) $\$ 15,000-\$ 19,999$

tal income)

8. How many children in family under 16? __ Over 16 ?

9. How many children over 16 years are SDA Church member?

10. What is your current church attendance pattern? ( ) No longer attend ( ) seldom attend ( ) Occasionally attend ( ) Regularly attend

11. Family experience provides different degrees of satisfaction for its members. How would you describe your current family experience? (Please circle number of scale.)

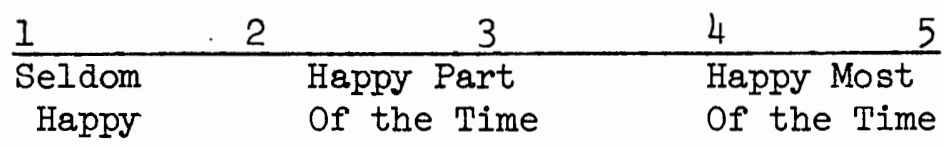


12. If you are experiencing marital unhappiness at present, how much of this unhappiness is related to difference in religious belief or cormitment? (Please circle the number that best describes your situation.)

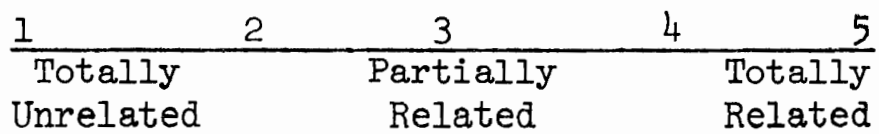

13. If you are experiencing (or have experienced) marital unhappiness due to religious differences, are such differences in:

( ) Religious belief? ( ) Religious practice?

14. Have you ever had marital counseling?

( ) Yes, with a pastor

( ) Yes, with physician

( ) Yes, with a professional counselor

() No

( ) Other

15. Would you use family marital counseling for problems?

() Yes
() No
() Undecided
() Would like more information about it

16. If you would use counseling service for problems, would you prefer counseling with:

( ) Pastor with special training

( ) Professional marriage counselor

( ) Professional social worker

( ) Family doctor

( ) Other

17. Is it important to you that the counselor be of your religious belief?
( ) Yes
() No
( ) Uncertain 
18. If you would not use counseling services for problems, indicate the reason:
( ) Do not believe in it
( ) Distance to counseling services too far
( ) Could not help problem
( ) Cannot afford it
( ) Don't know where to go for help
( ) Am afraid who might find out
( ) other

19. Would you attend a marriage/family seminar, workshop, or retreat to bring enrichment to your family life?
( ) Yes
( ) No
( ) Need more information

20. If you would not attend marriage/family seminars, workshops, or retreats, indicate reason( $s)$ :

( ) have no need

( ) could not help

( ) not interested

( ) other
( ) would have babysitting or child care. problems

( ) none offered in my area

21. Have you been through a divorce? ( ) Yes ( ) No

22. IF you have been divorced, was it:

( ) Before you became a SDA Church member

23. Was spouse a member at the time of divorce? ( ) Yes ( ) No

24. Would professional counseling have been helpful at the time?
( ) Yes ( ) No
( ) Maybe/uncertain

25. How much was your divorce related to religious differences?

\begin{tabular}{ccccc}
1 & 2 & 3 & 4 & 5 \\
\hline Not & Somewhat & \multicolumn{4}{c}{ Totally Due } \\
At All & & To Differences
\end{tabular}

26. Please list major strengths of your marriage. 
27. Please list factors that currently (or in the past) have brought unhappiness to your marriage.

28. If you are (or have been) divorced or separated, please list factors other than religion that contributed to the breakup of your home.

29. Please list ways the church could assist in bringing enrichment to your marriage and family. 
APPENDIX C

COVER LETTER FOR PIIOT QUESTIONNAIRE

\author{
Research Project \\ North Pacific Union Conference of \\ Seventh-day Adventists \\ 10225 East Burnside \\ Portland, OR 97216 \\ March 30, 1977
}

Dear Seventh-day Adventist church member:

A small number of church members have been selected to test a questionnaire that will soon be sent out to a very large randomly selected group of SDA members throughout The Pacific Northwest, as a part of the study mentioned in Elder Torkelsen's letter. The purpose of this test is to determine if the questions are clear and easy to understand or if there are any mechanical problems present in the questionnaire. Please read each question carefully and complete. If you have trouble understanding the meaning of the question, please check it and state in the margin the problem you had with it.

It is important that you complete the questionnaire and return it as soon as possible-not later than one week, in order for the study to continue according to schedule.

Thank you for cooperating in this test that will assist in the major study of family life within the Church.

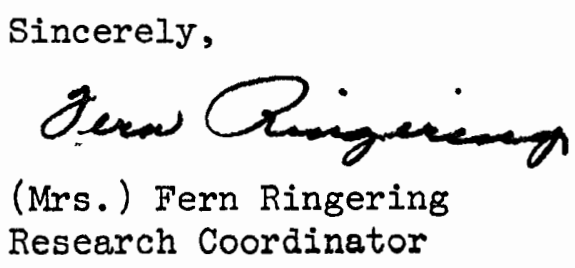


APPENDIX D

NEWS ITEM FROM MAY 16, 1977 ISSUE OF THE GLEANER PUBLISHED BY THE NORTH PACIFIC UNION

CONFERENCE OF SEVENTH-DAY ADVENTISTS

FOR THEIR CONSTITUENCY

\section{Family Life Survey}

Seventh-day Adventists have traditionally placed emphasis on the home and its importance to the strength of the church. However, the secular world seems to be advocating "emancipation from the confining restrictions" of family life with widely read and accepted books written against family life, such as David Cooper's Death of the Family. Church leaders are studying ways to help make Adventist families stronger and happier, because the church believes families must survive-in fact be strong and healthy -in order for the church to be effective and fulfill its commission.

In harmony with this belief a study on family life is being conducted among members in the North Pacific Union Conference to gather information that will aid in planning programs to help meet the needs of Adventist families. A sampling of NPUC membership is being randomly selected to participate in the study. The sampling members will re-

ceive a questionnaire about family life. While participation in this project is voluntary, questionnaire receivers are urged to complete and return the form immediately to enable the results to be representative of the entire union membership.

Survey questions were formulated by Seventh-day Adventist professionals in the fields of medicine, education, social work, mental health and the ministry. Research coordinator for the study is Mrs. Fern Ringering, master of social work candidate. Computor work and consultation is being supplied by the Regional Research Institute for Human Services, Portland State University. 
APPENDIX E

\section{SUMMARY SHEET GIVEN TO NORTH PACIFIC UNION CONFERENCE OFFICIALS}

Fact Sheet on Family Life Study being conducted by Fern Ringering, Master of Social Work Degree candidate, in cooperation with the North Pacific Union Conference of Seventh-day Adventists.

While church leaders and pastors are aware that the general breakdown of family life in the world today has also had an effect on Seventh-day Adventists and divorce within the church is increasing, little, if any, research has been conducted to assess the magnitude of the problem within the church.

This study is designed to gather the following information to assist in this assessment:

1. To at least partially determine the extent SDA church families are experiencing divorce.

2. To determine how this might be related to differences in religious commitment or belief.

3. To determine if SDA church members would utilize counseling/family services if such services were available that would be compatible with members' religious philosophy.

Method of gathering information:

Questionnaire will be mailed to a random selection of 500 church members taken from the North Pacific Union Conference computer membership list.

Expected return rate is at least 50\%. Respondents will make up the sample.

Questionnaire will be imprinted with return address and prepaid return postage. 
Quality of study:

Research advisors from the Regional Research Foundation of Portland State University will oversee the study to assure that it is scientifically sound.

A pilot study will be conducted to assure that the questionnaire is self-explanatory and questions are clear and also to get an idea of return rate.

Fifteen prominent denominational professionals have cooperated in the preparation of the questionnaire.

Study has been approved by the General Conference Home and Family Service.

Study time schedule:

Pilot study is planned for late March.

Overall study is expected to be done in late April or May.

Results will be tabulated and analyzed through the summer months.

Study should be ready for publication in the fall of 1977. (Requests have been received from two denominational publications for permission to publish study.)

NOTE: Questionnaire will have a cover letter of explanation from the North Pacific Union Conference President. 
SELECTED BIBLIOGRAPHY

BelI, R. R. Marriage and Family Interaction. 4th ed. (Homewood: Dorsey Press, 1975).

Blood, Robert $0 ., \mathrm{Jr}$. and Wolfe, Donald M. The Dynamics of Married Living. (New York: Free Press, 1965).

Burgess, Ernest W. and Locke, Harvey. J. The Family: From Institution to Companionship. 2nd ed. (Boston: American Book Company, 1953).

Burr, Wesley R. Theory Construction and the Sociology of the Family. (New York: John Wiley and Sons, 1973).

Duvall, Evelyn R. Faith in Families. (Chicago: Rand McNally, 1970).

Encyclopedia of Social Work. 17th ed. (New York: National Association of Social Workers, 1977) Vol. 1.

Faber, Adele and Mazlish, Elaine. Liberated Parents, Liberated Children. (New York: Avon, 1974).

Fishbein, Morris and Burgess, Ernest W. Successful Marriage. (Garden City: Doubleday and Company, 1955).

Ford, Edward E. Why Marriage? (Niles: Argus Communications, 1974).

Fullerton, Gail Putney. Survival In Marriage. (New York: Holt, Rinehart and Winston, Inc., 1972).

Herndon, Booth. 7th Day, The Story of Seventh-day Adventists. (New York: McGraw-Hill, 1963).

Kantor, David and Lehr, William. Inside the Family. (San Francisco: Jossey-Bass Publishers, 1976).

Klien, Phillip. From Philanthropy to Social Welfare. (San Francisco: Jossey-Bass Publishers, 1968).

Koch, Joanne and Koch, Lew. The Marriage Savers. (New York: Coward, McCann and Geoghegan, 1976).

Kurzman, Paul A. Relief in Medieval England - The Forgotten Chapter in the History of Social Welfare, Child Welfare \#49 (Nov. 1970).

Nye, F. Ivan. Role Structure and Analysis of the Family. (Beverly Hills: Sage Publications, 1976). 
74

Riven, Frances Fox and Cloward, Richard A. Regulating the Poor (New York: Random House, 1971).

Sally, Ruth A. Theory For Social Work Practice (New York: Columbia University Press, 1967).

Seventh-day Adventist Encyclopedia. (Washington, D.C.: Review and Herald Publishing Co., 1966).

Seventh-day Adventist Yearbook. (1977).

Skidmore, Rex and Milton Thackery. Introduction to Social Work (New York: Appleton-Century-Crafts, 1964).

Turner, Ralph H. Family Interaction. (New York: John Wiley and Sons, Inc., 1970).

White, Ellen G. The Adventist Home. (Nashville: Southern Publishing Association, 1954).

Wolins, Martins. Institution or Foster Family, A Century Debate (Child Welfare League). 